\title{
Necrotizing arteritis with giant cells associated with haemolytic anaemia
}

\author{
P. FLANAGAN, A. W. McCRACKEN, F. R. JONES, AND R. M. CROSS \\ From the Royal Air Force Institute of Pathology and Tropical Medicine, Halton, Bucks
}

SYNOPSIS Necrotizing arteritis with giant cells, involving the aorta, pulmonary and coronary arteries, and coronary, splenic, and renal arterioles was found at necropsy in a 74-year-old male who had died with severe haemolytic anaemia associated with cold haemagglutinins.

The clinical and pathological features of this case are shared by well-recognized forms of necrotizing angiitis, in particular giant cell arteritis, but do not conform satisfactorily with any of these disorders. Cold agglutinin haemolytic anaemia in this instance suggests the possibility of an autoimmune aetiology.

The absence of a completely satisfactory classification of the various forms of necrotizing angiitis reflects the considerable overlap of clinical and pathological features among these conditions. This report of a patient whose features were not typical of any one syndrome gives weight to the concept that the various forms of necrotizing angiitis are a spectrum of vascular disease which includes giant cell arteritis, Wegener's granulomatosis, the ChurgStrauss (1951) syndrome, and polyarteritis nodosa.

\section{CASE REPORT}

A 74-year-old man entered hospital on 20 April 1963, because of jaundice of one day's duration. He had had chronic cough with sputum and exertional dyspnoea for many years. He had experienced gradual loss of vision of the left eye and left parotid swelling four months before admission. The parotid swelling subsided slowly and spontaneously. One month later he had increasing shortness of breath and a right pleural effusion. Thrombophlebitis developed in the right calf a week later. The thrombophlebitis resolved following penicillin, tetracycline, and anticoagulant therapy.

When he was admitted, fundal examination showed left optic atrophy. He was severely anaemic ( $\mathrm{Hb} 6.9 \mathrm{~g}$. per $100 \mathrm{ml}$.). The white blood cell count was 15,000 per c.mm. with a differential count of $70 \%$ neutrophils, $2 \%$ eosinophils, $22 \%$ lymphocytes, and $6 \%$ monocytes. There were only $1 \%$ reticulocytes. The red cells were normochromic and normocytic; platelets appeared normal. Erythrophagocytosis was present in the blood films and marked autoagglutination was noted in all blood tests.

The patient's blood group was 0 rhesus positive. A serum cold agglutinin against the patient's own red cells and against stock 0 rhesus-positive cells was demonstrated

Received for publication 1 March 1965. to a titre of $1 / 512$ at $4^{\circ} \mathrm{C}$, and $1 / 32$ at $20^{\circ} \mathrm{C}$.; there was no agglutination at $37^{\circ} \mathrm{C}$, , but there was a positive direct antiglobulin test at this temperature. There was no Donath-Landsteiner antibody present. Thrombotest (Owren) showed $11.5 \%$ coagulation activity. Plasma protein was $5.8 \mathrm{~g}$. per $100 \mathrm{ml}$. On paper strip plasma protein electrophoresis, there were two haptoglobin bands, an intense band with the beta-globulins and a less intense one with the alpha-globulins.

Hyland screening tests for lupus erythematosus, thyroiditis, and rheumatoid arthritis were each negative. Immuno-chemical studies to identify further the cold haemagglutinin were not done nor was it possible to ascertain any blood group specificity.

Serum bilirubin was $3.4 \mathrm{mg}$. per $100 \mathrm{ml}$; alkaline phosphatase, 15 King-Armstrong units per $100 \mathrm{ml}$.; serum glutamic-pyruvic transaminase, 10 Sigma-Frankel units per $100 \mathrm{ml}$.; urea $51 \mathrm{mg}$. per $100 \mathrm{ml}$. Urine analysis was normal.

The patient had progressive severe respiratory distress and died 36 hours after admission to hospital.

NECROPSY

Both upper lobes of the lungs were studded with emphysematous blebs and cysts. The lower lobes were wet, heavy, and speckled with many small collections of pus. There was $30 \mathrm{ml}$. of clear pericardial effusion. The myocardium was mottled with small grey scars. The heart weighed $330 \mathrm{~g}$. The coronary arteries were irregularly thickened with eccentric firm white nodular swellings which partly occluded the lumen; there were several segments with yellow, calcified walls. The aorta contained many areas of yellow subintimal thickening. The spleen weighed $70 \mathrm{~g}$. and appeared normal on cut 
section. The rest of the gross necropsy examination was unremarkable.

\section{HISTOLOGICAL EXAMINATION}

Sections of the lung showed widespread necrotizing bronchopneumonitis associated with vegetable and meat fibres. There was arteriosclerosis of the pulmonary arteries with eccentric subintimal swelling of loose connective tissue and segmental loss of the internal elastic lamina; the media contained small foci of giant cells and a variable number of histiocytes and lymphocytes (Fig. 1). Scattered throughout the vascular bundles of the lung were numerous areas of fibrosis in which occasional round cells were found. There were no eosinophils or giant cells in these areas.

The entire outer two-thirds of the wall of the aorta was replaced by masses of chronic inflammatory cells with eosinophils and multinucleate giant cells. The muscle and elastic fibres were fragmented and displaced by these cells (Fig. 2). The internal elastic lamina was preserved. The adventitia of the aorta also contained numerous inflammatory cells, especially around the vasa vasorum. There was no pallisading or zoning within any of the inflammatory sites.

The sections of the heart demonstrated a widespread segmental necrotizing and occlusive process within the coronary arteries. A loose amorphous swelling destroyed the internal elastic lamina, elevated the intima and attenuated and displaced the media. This swelling was rich in acid mucopolysaccharides by alcian blue staining. At the margin of this swelling were round cells, eosinophils, multinucleated giant cells, and a few small masses of homogeneous eosinophilic fibrinoid. Some of the arterioles showed similar material in the intima as well as foci of giant cell granulomatous reaction in the media and adventitia (Fig. 3). There were broad interlacing bands of fibrous tissue throughout the myocardium, within which were swollen rounded myocardial fibres and occasional foci of giant cells, round cells, and eosinophils without fibrinoid (Fig. 4).

In the spleen there was marked haemosiderosis, and prominent dilatation of empty sinusoids. The penicilliary arteries and arterioles showed bright red hyaline intimal thickening; several contained inflammatory foci with giant cells in the media and adventitia (Fig. 5). These foci were devoid of organisms on Gomori's methenaminesilver,Ziehl-Neelsen, and Brown and Brenn stains.

The interlobular arteries of the kidney also contained several giant cell inflammatory foci similar to those in the heart and the spleen (Fig. 6). There

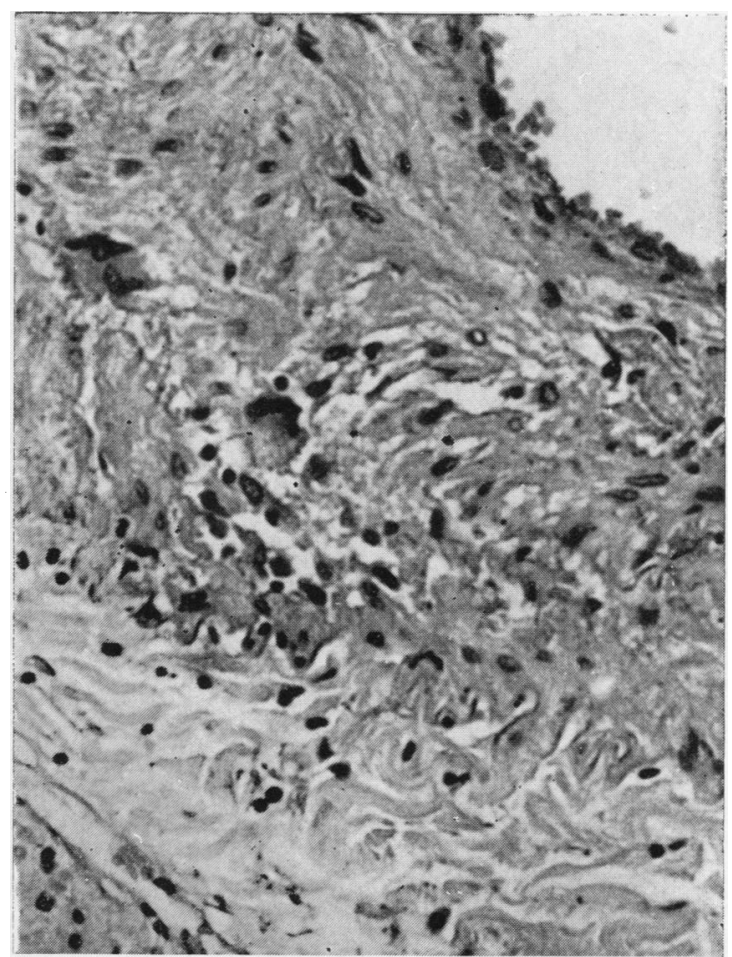

FIG. 1. Section through wall of pulmonary artery to show giant cell and round cell infiltration of the media. Haematoxylin and eosin $\times 200$.



FIG. 2. Masses of round cells have invaded the media of the aorta and displaced the elastic fibres. Van Geison elastic stain $\times 200$. 


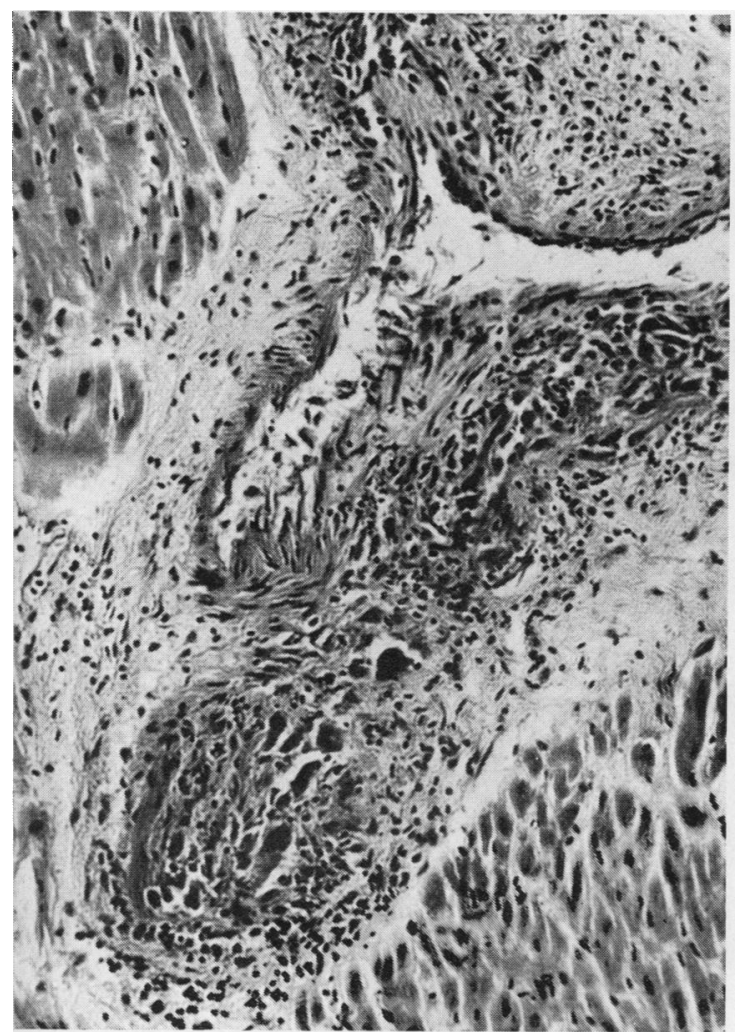

FIG. 3 .

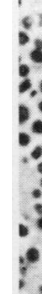

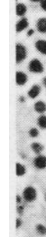

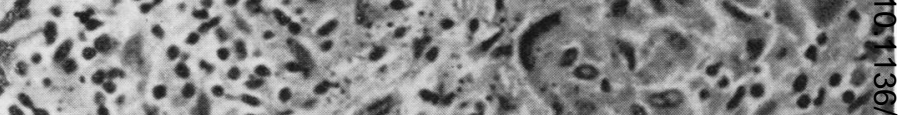



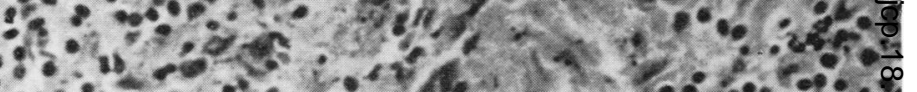







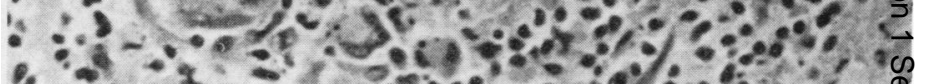

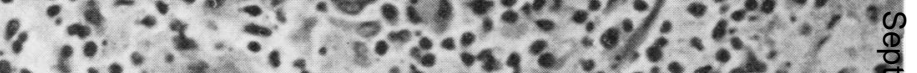

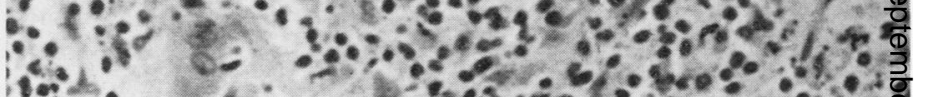
is:

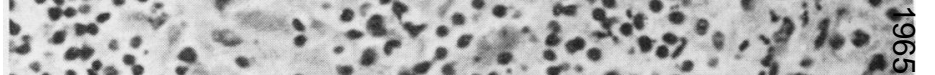

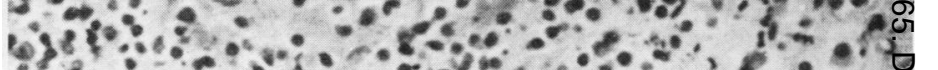
FIG. 5.

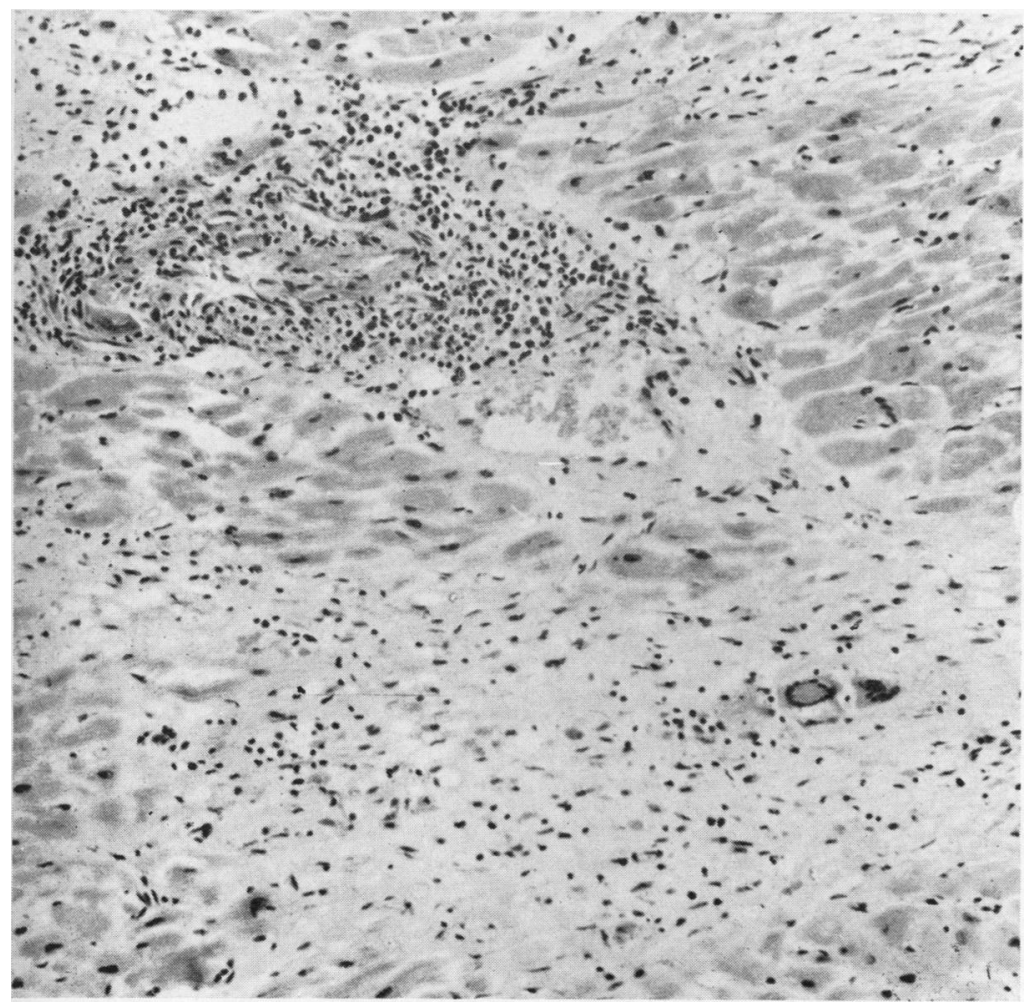

FIG. 3. Multifocal necrotizing giant cell vasculitis affecting smaller coronary vessels. Haematoxylin and eosin $\times 100$.

FIG. 4. There is giant cell arteritis about the arteriole in the upper field, and giant cell myocarditis in the scar in the lower field. Haematoxylin and eosin $\times 100$.

FIG. 5. Segment of splenic arteriole destroyed by necrotizing inflammation with giant cells, epithelioid cells, and round cells. Haematoxylin and eosin $\times 200$.

FIG. 4. 




FIG. 6. This view of the kidney shows giant cell inflammation about a renal arteriole. The black deposits in the tubules contain iron and represent haemoglobin. Haematoxylin and eosin $\times 225$.

was focal round cell infiltration around the interlobar and arcuate arteries. The glomeruli and tubules were unaffected.

The bone marrow appeared normal.

\section{DISCUSSION}

While many features of this case are shared by wellrecognized forms of necrotizing angiitis, they are not typical of any one of these disorders. The beaded eccentric nodules occluding the coronary arteries were grossly typical of polyarteritis nodosa (Ophüls, 1923). Microscopically the giant cell component of the inflammatory process is not found in polyarteritis. The complete absence of characteristic necrotizing granulomatous lesions in the respiratory tract excludes Wegener's granulomatosis. The myocardial scarring and giant cell foci were not those seen in the Churg-Strauss syndrome, which displays an epithelioid cell reaction around foci of eosinophilic necrosis surrounding small vessels, with an outer zone of eosinophils and mononuclear cells, but without giant cells (Churg and Strauss, 1951; Abul-Haj and Flanagan, 1961). Again, in giant cell myocarditis, the inflammatory foci lie between muscle fibres, pushing them apart (Dilling, 1956); here, however, the giant cell foci were found on serial section to be close to small branches of the coronary arteries and arterioles. There were no manifestations of disseminated lupus erythematosus, scleroderma, rheumatic fever, or 'hypersensitivity' angiitis.

In several aspects, the disease process described was similar to giant cell arteritis. There was evidence of involvement of the carotid system in the optic atrophy which occurred four months before death. The histological appearances of the mesaortitis were identical with giant cell arteritis; the distribution and appearances of lesions in the pulmonary, splenic, and renal muscular arteries were similar to those described in certain instances of this disease (Harrison, 1948; Heptinstall, Porter, and Barkley, 1954; Lander and Bonnin, 1956; Ainsworth and Gresham, 1961). However, neither the involvement of small arteries and arterioles of the heart, spleen, and kidneys, nor the presence of an acute haemolytic process reported here, have been associated with giant cell arteritis.

Severe anaemia and the presence of active erythropoiesis, hyperbilirubinaemia with a normally functioning liver, erythrophagocytosis and autoagglutination of red cells were proof of a haemolytic process, even although red cell survival times were not obtained and the spleen was not enlarged. The 
normal size of the spleen suggested that the haemolytic process was of recent origin. The presence of a cold haemagglutinin with a positive direct antiglobulin test indicated an auto-immune origin to the haemolytic process.

The occurrence of cold antibodies in this instance of arteritis suggests disordered plasma protein metabolism (Kunkel, Fudenberg, and Ovary, 1960), and a relationship to certain conditions in which dysglobulinaemia occurs: polyarteritis nodosa (Fundenberg, German, and Kunkel, 1962), rheumatoid arthritis, rheumatic fever, and lupus erythematosus (Wolf, Gokcen, and Good, 1963; Videbaek, 1962). Instances of giant cell arteritis have shown disorders of plasma protein metabolism. Small and Gavrilescu (1963) found elevated alpha 2 glycoprotein with marked elevation of alpha ${ }_{2}$ globulins and slight elevation of gamma globulins. These abnormalities were corrected by adrenal steroid therapy. Whitfield, Meynell, Fessey, and Hudson (1962) described a patient with giant cell arteritis in whom there was a circulating factor VIII inhibitor which disappeared on steroid therapy.

Further elucidation of the relationship of the various forms of vasculitis to the dysglobulinaemias may appear with more complete plasma protein analyses in patients with these disorders.

The views expressed herein do not necessarily represent those of the Surgeon General U.S.A.F. The authors wish to thank Air Commodore W. P. Stamm for his advice, and the Director General of Medical Services, R.A.F., for permission to publish.

\section{REFERENCES}

Abul-Haj, S. K., and Flanagan, P. (1961). Med. Ann. D.C., 30, 670. Ainsworth, R. W., and Gresham, G. A. (1961). J. Path. Bact., 82, 203. Churg, J., and Strauss, L. (1951). Amer. J. Path., 27, 277.

Dilling, N. V. (1956). J. Path. Bact., 71, 295.

Fudenberg, H., German, J. L., III, and Kunkel, H. G. (1962). Arthr. and Rheum., $5,565$.

Harrison, C. V. (1948). J. clin. Path., 1, 197.

Heptinstall, R. H., Porter, K. A., and Barkley, H. (1954). J. Path. Bact., 67, 507.

Kunkel, H. G., Fudenberg, H., and Ovary, Z. (1960). Ann. N. Y. Acad. Sci., 86, 966.

Lander, H., and Bonnin, J. M. (1956). J. Path. Bact., 71, 369.

Ophüls, W. (1923). Arch. intern. Med., 32, 870.

Small, J. M., and Gavrilescu, K. (1963). J. Neurol. Neurosurg. Psychiat. 26, 257.

Videbaek, A. (1962). Acta med. scand., 171, 187.

Whitfield, H. E. W., Meynell, M. J., Fessey, B. M., and Hudson, W. A. (1962). J. clin. Path., 15, 357.

Wolf, J. K., Gokcen, M., and Good, R. A. (1963). J. Lab. clin. Med., 61, 230. 